\title{
Women's Representation in Media News During the Japanese Period
}

\author{
$1^{\text {st }}$ Wulandari Dwianty Putri \\ Student of Dep. of Historical Education, \\ Faculty of Social Studies, \\ Universitas Negeri Padang, \\ Padang, Indonesia \\ wulandwidariii@gmail.com
}

\begin{abstract}
The purpose of this study are: 1) to describe the lives of women during the Japanese occupation in Indonesia; 2) to describe the representation of women in Japanese media news. This research is a qualitative research that is as a research procedure that produces descriptive data. This research uses mass media, namely newspapers published during the Japanese period as the main data. News in Japanese newspapers shows that the activities carried out during the Japanese occupation by women were working in factories, military training, becoming
\end{abstract}

\section{INTRODUCTION}

Representation is the relationship between the concepts of mind and language that allows the reader to point to the real world of an object, reality, or to the imaginary world of fictitious objects, humans or events. So representation is the process by which members of a culture use language to produce meaning. Language in this case is defined more broadly, namely as any system that uses signs that can be verbal or nonverbal. The notion of representation has an original or fixed meaning (the true meanings) inherent in itself [1].

Mass media (mass media) consists of two words, namely "media" and "mass". The word media is close to the meaning of "medium", "moderta" which means middle, medium, mediator or connector. Or socially politically, "media" is a place, vehicle, forum, or more

\author{
$2^{\text {nd }}$ Siti Fatimah* \\ Lecturer of Dep. of Historical Education, \\ Faculty of Social Studies, \\ Universitas Negeri Padang, \\ Padang, Indonesia \\ sitifatimah@fis.unp.ac.id
}

teachers, being nurses and being required to attend special girls' schools. Here it appears that the figure of women must be able to help not only in the domestic sector but also the public and mixed. Women in the mass media of newspapers in the Japanese period found that women represented as a tough figure, have a strong mentality, but have a pure and gentle soul.

Keywords-Representation, Women,

Japanese Occupation, Japanese Mass Media precisely an intermediary institution. Medium "mass" is something that is not personal, something that is not personal, but something that is associated with many people. Thus the mass media is a neutral institution that deals with people or institutions that are neutral for all groups or societies [2], [3]. In the case of mass media we are familiar with the terms print media (press) and broadcast media. The understanding of print media includes all printed matter including books, but in its development the understanding of print media has been reduced to newspapers/magazines/ tabloids [2], [3]. While the meaning of broadcast media is radio and television [2], [3].

Women in Indonesia are represented through various mass media such as women in prehistoric times represented through a megalithic statue located in Pasemah, South Sumatra. Women's statues are less found than 
men's statues because domestic roles are mostly done by women because of certain considerations, for example childcare requires a female figure because giving birth and breastfeeding activities can only be done by women [4].Women in the Dutch colonial period were represented through films and novels that told the life of the Dutch colonial era. In the novel Bumi Manusia, the character Nyai Ontosoroh is represented as an independent female figure. An attitude that must also be developed by the peopleof Indonesia (Indigenous). Building awareness of the nationalism throughthe build awareness of identity as Indigenous - a status that is always distinguished from the Netherlands (Europe). For Nyai Ontosoroh, awareness of identity as pribumi that is free from inferior feelings will determine the fate of the nation in the future. Trying to oppose the Dutch colonial power, through the symbol of his struggle against the Dutch East Indies law to obtain the rights to property and children left by Herman Mellema[5].

During the Japanese occupation, women didn't get many opportunities, because every movement always received strict supervision from the Japanese kempetai. To follow the wishes of the Japanese Government, when the Three a Movement was formed, the Three Wife A movement was formed with its leader $\mathrm{Ny}$. Artinah Syamsuddin. The movement is equipped with a princess, which is called Barisan Putri Asia Raya. With the formation of Center for People's Power- Pusat Tenaga Rakyat (PUTERA) in March 1943, the line of work of PUTERA women was also formed part of their women [6], [7].

Besides the movement, the Japanese government established the Fujinkai (Women's Organization) whose special position was to accommodate all forms of women's activities. Fujinkai was established from the central to the lower levels and its name was in accordance with the level and place of its position, such as ken for the district level and is for the city. The leaders of this association are the wives of Kenko (regent). Thus Fujinkai is a must for mothers or civil servants starting from the top level to the sub-district area. Its members are required to mobilize female workers in their respective places, while those who are members are girls aged 15 years and over. Fujinkai membership is also open to foreigners.

On November 3, 1943 in Jakarta Tokobetsusi was founded with its leader Ny. R.A. Abdirrachman. This association was then complemented by the establishment of Barisan Putri with Siti Dahlia and Nursyamsu as their representatives. The assistants included Setiati, Malidar and Paramitra Rahayu Abdurrachman [8], [7]. In the context of cadre printing, Barisan Puteri conducted training at the Megaria Jakarta Cinema. The activity was carried out in stages and was attended by 50 people. The participants consisted of girls as representatives from subdistricts throughout Jakarta and outside Jakarta. The lessons given are military training, Family Skills Education-Pendidikan Keterampilan Keluarga (PKK), absurdly and others. In addition there are skills such as spinning yarn, weaving, singing practice and radio broadcasts. To add insight every two days, lectures from national figures are always held including Muhammad Hatta and Sutan Syahrir [9][7].

In January 1945 Jawa Hokokai stood alone under the name Java Hokokai Fujinkai Jimukyoku, and the young man was called Joahi Seinenkai with his leader Siti Maryono, Ny. Maryati Adnan and Ny. Rosnah Jamin. Since the March was prepared behind the war line, the March was given abysmal training, marching, using weapons, air hazard training, visiting hospitals, holding public kitchens, traveling kitchens, permanent kitchens and defense kitchens.

Fujinkai's efforts include: a)stimulating the spirit of love for the motherland and nation among women and instilling nationalism; b)encourage sacrifice and be willing to suffer for the motherland and the nation; c)preparing power to participate behind the battle lines; d)encourage regular living and frugality; e)increase crop yields by planting all land with 
food-producing plants and clothing including yams, jatropha, cotton and others; f)turning on handwork and industrial work at home including spinning yarn, making socks; g)carry out necessary exercises; h)turning on jobs to eradicate unemployment[10], [7]. Judging from the activities carried out by Fujinkai in essence, it is inseparable from the predetermined lines as enshrined in Java Hokokai which includes the implementation of everything in a real and sincere way to contribute all energy based on the spirit of brotherhood between all nations and to strengthen the defence of the motherland.

Judging from the activities carried out by Fujinkai in essence, it is inseparable from the predetermined lines as enshrined in Java Hokokai which includes the implementation of everything in a real and sincere way to contribute all energy based on the spirit of brotherhood between all nations and to strengthen the defence of the motherland. In the middle of 1944 the forces of the Japanese Army were increasingly pushed by Allied forces. In connection with this situation, the Japanese government apart from existing agencies such as Keibondan (Police Assistance), Seinendan (Youth Front), Heiho (Warrior Assistance), and Defender of the Motherland-Pembela Tanah Air (PETA) also feel the need to form the Srikandi rank and this body is part of from Fujinkai. These troops are really prepared as combat troops, because they have been equipped with a variety of knowledge about the military, so that the troops already have sufficient skills and abilities [6], [7].

At the end of the Japanese occupation, conditions were tinged with distress, food and clothing were hard to come by, Romushaspread to mainland Asia as forced labour and it was their turn to be wasted human beings because they no longer received proper attention, so many of them just disappear. To return to my hometown there is no power to support it. To compensate for the increasingly precarious situation, Fujinkai's umbrella women took to the field to enlighten mothers in the Tanorigumi (Neighborhood Association) area in an effort to make austerity. In addition, they also work on rice fields and fields such as planting rice, planting cotton and jatropha [10], [7]. In order to ease the burden of Romusha's suffering, Fujinkai voluntarily moved to collect used clothing which was then given to Romusha. Because of the difficulty of getting clothing materials, for this purpose forced to make clothes from gunny sack as Fujinkai Surabaya just relieve the suffering of Romushawho was working on the south coast of the island of Java [10]. In addition to providing modest clothing, Fujinkai also cared for and sought treatment for a sick Romusha until healed [7].

Based on the description above, during the Japanese period women were represented through the mass media. In this paper the authors use the mass media in the form of newspapers with the aim to: 1 ) describe the lives of women during the Japanese period in Indonesia, 2) describe the representation of women in Japanese media news.

\section{METHOD}

This study uses qualitative research to produce descriptive data using content analysis methods and data obtained from discourse data. Content analysis is a method for studying and analysing communication systematically, objectively and quantitatively to the messages that appear[11] [12]. Content analysis is a research technique for making inferences that can be replicated (authentic) and validated by observing the context of the data [13] [12]. Content analysis is a research method using a set of procedures to make valid inferences from texts [11] [12].The author uses discourse data to describe the representation of women in the news in newspapers circulating during the Japanese period. Data discourse is obtained from news in newspapers in the Japanese period. The author groups female figures found in the news in newspapers in the Japanese period which then represents women in the Japanese period according to the female figures that have been grouped using tables to produce descriptive data. 


\section{RESULTS AND DISCUSSION}

Based on the news found in a newspaper in the Japanese period, the writer groups female figures as follows:

Table 1 Figure of Women in News of Japanese Newspapers

\begin{tabular}{|c|c|c|c|c|c|}
\hline No. & Representation of Women in Japan Period & Public & Domestic & Mix & Sources \\
\hline 1. & $\begin{array}{l}\text { Women as workers in the Nippon Workers (Hantih) } \\
\text { Thread Manufacturing Company }\end{array}$ & Worker & & & [14] \\
\hline 2. & Women become students at the Putri Wakaba School & & Student & & [14] \\
\hline 3. & $\begin{array}{l}\text { Women in the village are cultivating paddy fields and } \\
\text { ponds }\end{array}$ & & Farmer & & [15] \\
\hline 4. & Women in the village become voluntary ranks & Army & & & [15] \\
\hline 5. & Women in the village lead the nursery & Teacher & & & [15] \\
\hline 6. & $\begin{array}{l}\text { Women in the city voluntarily work in factories for war } \\
\text { purposes }\end{array}$ & Worker & & & [15] \\
\hline & Woman as Nurse & & & Nurse & [16] \\
\hline & Woman as Army of Dai Nippon & Army & & & [17] \\
\hline & Female students help harvest in paddy fields & & Farmer & & [18] \\
\hline 10. & Women as workers in the factory of war equipment & Worker & & & [18] \\
\hline & $\begin{array}{l}\text { Women to help the war effort with the formation of the } \\
\text { Heroine Army (Barisan Srikandi) }\end{array}$ & Army & & & [19] \\
\hline 12. & $\begin{array}{l}\text { Women are educated to be able to carry out their lives } \\
\text { by receiving training on resisting air hazards, fire } \\
\text { hazards, and helping if there is an accident }\end{array}$ & Army & & & [20] \\
\hline 13. & $\begin{array}{l}\text { Women should be aligned with the nature of the body } \\
\text { that has shown the basis of certain jobs, especially } \\
\text { mothers and women such as maintaining the health of } \\
\text { infants }\end{array}$ & & & Nurse & [20] \\
\hline 14. & $\begin{array}{l}\text { Women are trained to become leaders of the Nippon } \\
\text { Women by training in a line up with the troupe }\end{array}$ & Army & & & [21] \\
\hline & $\begin{array}{l}\text { Women are ready to replace male workers to work at } \\
\text { the Post Office }\end{array}$ & Worker & & & [22] \\
\hline & $\begin{array}{l}\text { Women are also required to work actively and their } \\
\text { energy is used in offices, companies and schools }\end{array}$ & Worker & & & [23] \\
\hline & $\begin{array}{l}\text { Women are reviving yarn scouts to provide jobs to } \\
\text { residents and to meet the fiber needs }\end{array}$ & Worker & & & [24] \\
\hline & $\begin{array}{l}\text { Women grow cotton, sweet potatoes, cassava,corn on } \\
\text { the ground around the house }\end{array}$ & & Farmer & & [24] \\
\hline & $\begin{array}{l}\text { Woman studying in the training school for female } \\
\text { teachers }\end{array}$ & Teacher & & & [25] \\
\hline & Women run kitchen businesses to meet the daily needs & & $\begin{array}{l}\text { House- } \\
\text { wife }\end{array}$ & & [26] \\
\hline
\end{tabular}

This table was made by Wulandari Dwianty Putri

Based on the table above, the figure of women in Japan was divided into:
1. The figure of women during the Japanese era in the public sphere is evident from the 
news that women became workers in yarn factories, workers of war equipment factories, became air defence soldiers, became members of the rearguard on the battlefield, became employees at the post office to become teachers for schools schools especially girls' schools.

2. The figure of women in Japan in the domestic sphere is evident from the news that women are required to study at a girls 'school to learn cooking, washing-washing, sewing, to arranging flowers in a girls' school, women are required to grow cotton, sweet potatoes, corn, and cassava on the ground around the house, as well as guarding the house when father, husband, brother and even boys go to war.

3. The figure of women in the Japanese era in the field of mixture was apparent from the news that women studied at nursing school and after graduating they had to go straight into battle to help victims injured by enemy attacks.

\section{Gender Theory}

The term "gender" was first introduced by [27], [28] to separate human traits based on socio-cultural definitions from definitions derived from biological physical features. In social science the person who was also instrumental in developing gender terms and understanding is [28]. Like Stoller, Oakley defines gender as a social construction or attribute imposed on humans that is built by human culture. In the Complete Dictionary of Modern Social Thought, "gender relations" are defined as social relations between men and women. Gender is distinguished from biological relations between sexes, because gender relations are relationships that are socially constructed. The nature of gender relations varies from time to time and place, changes over time and shows diversity according to culture and social location. Descriptions of gender relations patterns also vary in terms of different domain priorities and different levels of abstraction [27], [28]. Gender is constructed and expressed in many social institutions, including culture, ideology, and discursive practices. Gender is part of the division of labor between men and women at home, especially between husband and wife. Gender relations take different forms in different countries, in different ethnic groups, different social classes and different generations. Nevertheless all have the same in distinguishing between men and women, although there are social variations in the nature of these differences. In the book Dr. Riant Nugroho said that gender relations questioned the position of women and men in the distribution of resources and responsibilities, benefits, rights, power and privileges. The use of gender relations as a category of analysis no longer focuses on women who are seen as isolated from men.

The concept of gender that is understood by most people is often biased and is interpreted very narrowly as a concept that only addresses the problem of women with their female nature. Whereas gender differs from gender, it does not only talk about women or men, not also the concept of biological differences that both have. Gender is the different roles of men and women that are constructed (built) by the community or community groups with different cultural backgrounds and social structures in each region, ethnicity, state and religion. Therefore, the different roles, behaviours, characteristics of men and women that apply in a place / culture may not necessarily be the same or apply in different places.

Understanding gender also includes discussing relations between women and men and the ways in which relationships are built and supported by the community. Like the concepts of class, race and ethnicity, gender is an analytical tool for understanding social relations between women and men. Until now, barriers to the realization of equality between women and men are mostly caused by the disparity in women and men constructed by society. The relationship gap is influenced by historical, cultural, economic and religious factors that are deeply rooted in generations among the people. 
This reality has an impact on the lives of women and men in their daily lives, both in the domestic (household) and in the public domain (society, the world of work, education). A new paradigm is needed to provide a framework and explain the relationships (relations) between women and men in various walks of life, formal institutions and informal institutions including family institutions. Strategies for change are needed, namely how to change relations (relations) between women and men that are gender responsive so that gender equality and equity are realized[28].

\section{Representation Theory}

Stuart Hall's representation theory shows a process in which meanings are produced using language and exchanged between group members in a culture. Representation connects concepts in our minds by using language that allows us to interpret objects, people, real events, and the imaginary world of objects, people, objects, and events that are not real (fictional) [29], [1].The theory put forward by Hall is very helpful in further understanding of what the meaning of representation is and how it operates in a cultural society. Representation is an essential part of the process by which meaning is produced and exchanged between members of culture. Through representation, a meaning is produced and exchanged between members of the community. So it can be said that, a brief representation is one way to produce meaning. Representation works through a representation system that consists of two important components, namely concepts in mind and language. These two components are correlated. The concept of something that is owned and exists in the mind makes a person or person know the meaning of something. However, meaning cannot be communicated without language, as a simple example, the concept of 'glass' and knowing its meaning. Then someone will not be able to communicate the meaning of 'glass' (the object that people use for drinking places) if someone can't express it in a language that can be understood by others.
Therefore, the most important thing in a representation system is that groups that can produce and exchange meaning well are certain groups that have common background knowledge so that they can create an (almost) same understanding. Thinking and feeling is also a system of representation, as a system of representation means thinking and feeling also function to interpret something. To be able to do this, the same background of understanding of the concepts, images and ideas (cultural codes) is needed. The meaning of something can be very different in different cultures or groups of people, because in each culture, group, and community there are certainly different ways to interpret something. Groups of people who have different backgrounds in understanding certain cultural codes will not be able to understand the meaning produced by other community groups. Representative theory is like using a constructionist approach, which argues that meaning is constructed through language. Stuart Hall [16] in his article, "thigs dont" means: we construct meaning, using representational systems-concepts and signs. Therefore the concepts in (mind) and sign (language) become an important part that is used in the process of construction or production of meaning. So it can be concluded that representation is a process to produce meaning from concepts that exist in our minds through language. The process of producing meaning is made possible by the presence of a representation system. However, the meaning process depends on the background knowledge and understanding of a social group to a sign. A group must have the same experience to be able to interpret something in almost the same way[1].

Based on the results above, the figure of women in the Japanese period did not so much take over the domestic sphere but took over the public sphere caused by the Japanese government lacking manpower to carry out the work that must be done by men because men had to go down to war. In this case, it appears that gender relations between men and women have changed. That should have been done by 
men, but in Japan all jobs requiring men were done by women.The figure of women in the mass media (newspapers) that circulated during the Japanese era represented women as a person who was tough, had a strong mentality, but had a pure and gentle soul in carrying out their work and daily lives.

\section{CONCLUSIONS}

Based on the results and discussion it can be concluded that the news in Japanese newspapers shows that the activities carried out during the Japanese occupation by women were working in factories, military training, becoming teachers, becoming nurses and being required to attend special schools women. Here it appears that the figure of women must be able to help not only in the domestic sector but also the public and mixed. Women in the mass media of newspapers in the Japanese period found that women represented as a tough figure, have a strong mentality, but have a pure and gentle soul.

\section{REFERENCES}

[1] Suharman, Sigit. (2014). Respresentasi Perempuan Metropolitan dalam Film 7 Hati 7 Cinta Wanita. Jurnal Komunikasi, 3(1), pp. 39-63.

[2] Hari, Niryawan. (2007). Dasar-Dasar Hukum Media. Yogyakarta: Pustaka Pelajar.

[3] Makhshun, Toha dan Khalilurrahman. (2018). Pengaruh Media Massa dalam Kebijakan Pendidikan. Ta'dibuna: Jurnal Pendidikan Agama Islam, 1(1), pp. 57-68.

[4] Triwurjani, Rr. (2015). Arca Perempuan dan Arca Laki-laki pada Kelompok Arca Megalitik Pasemah, Sumatera Selatan: Perpespektif Gender. Jurnal.

[5] Adji, Muhamad. (2010). Peran Perempuan Indonesia dalam Perjuangan Kebangsaan (Membaca Tokoh Nyai Ontosoroh pada Novel Bumu Manusia). Yinyang Jurnal Studi Gender dan Anak, 5(2), pp. 261-272.
[6] Manus, MPB. (1985). Peranan Wanita Indonesia Di Masa Perang Kemerdekaan (1945-1950). Jakarta: Depdikbud.

[7] Sondarika, Wulan. (2017). Peran Wanita dalam Perjuangan Kemerdekaan Indonesia Masa Pendudukan Jepang. Jurnal HISTORIA, 5(2), pp. 2337-4713.

[8] Mukmin, Hidayat. (1980). Beberapa Aspek Perjuangan Kaum Wanita. Jakarta: Binacipta.

[9] Panitia Kongres Wanita Indonesia. (1986). Sejarah Setengah Abad Kesatuan Pergerakan Wanita Indonesia. Jakarta: Balai Pustaka.

[10] Lasmidjah, Hardi,. (1984). Kumpulan Pengalaman dan Pemikiran. Jakarta: Sinar Harapan.

[11] Eriyanto. (2015). Analisis Isi: Pengantar Metodologi untuk Penelitian Komunikasi dan Ilmu Sosial Lainnya. Jakarta: Prenanda Media.

[12] Ahmad, Jumal. (2018). Desain Penelitian Analisis Isi (Content Analysis). Retrieved from www.research gate.net/publication/326935331

[13] Krippendorff, Klaus. (1991). Content Analysis: an introduction ot its Methodology. London: SAGE Publucations.

[14] Djawa Baroe. Jilid 1. No. 2. 2603 (1943)

[15] Djawa Baroe. Jilid 3. No. 15. 2064 (1944)

[16] DjawaBaroe. Jilid 4. No. 17. 2064 (1944)

[17] DjawaBaroe. Jilid 4. No. 21. 2064 (1944)

[18] DjawaBaroe. Jilid 4. No. 23. 2064 (1944)

[19] Berita Tanam Isteri dalam Tjahaja. Senin 6 April 2604 (1944)

[20] Djawa Baroe. Jilid 4. No. 8. 2064 (1944)

[21] DjawaBaroe. Jilid 4. No. 11. 2064 (1944)

[22] Asia Raya. 17 September 2604 (1944)

[23] Djawa Baroe jilid 1 No. 7. 2603 (1943) 
[24] Djawa Baroe jilid 5 No. 11. 2065 (1945)

[25] Djawa Baroe jilid 1 No. 5. 2603 (1943)

[26] Djawa Baroe jilid 5 No. 10. 2065 (1945)

[27] Nugroho, Riant. (2008). Gender dan Strategi Pengaruh Utamaannya di Indonesia. Yogyakarta: Pustaka Pelajar.

[28] Puspitarini, Dwi dan Femilia, Praptika Septi. (2018). Relasi Gender dan
Kehidupan Sosial Ekonomi dalam Keluarga Buruh Tani Perempuan di Kecamatan Panti Kabupaten Jember. An'nisa, 11(2), pp. 117-144.

[29] Hall, Stuart. (2003). The Work of Representation, Representation: Cultural Representation and Signifying Practices. Ed. London: Sage Publication. 